\title{
Smallholder Subsistence Agriculture: Why Ethiopia is Still Here?
}

\author{
Gebrerufael Girmay ${ }^{1 *}$
}

\author{
Center for Rural Development, College of Development Studies, Addis Ababa University
}

\begin{abstract}
Ethiopia is an ancient country with unparalleled history. It has introduced and practiced agriculture no later than the first. However, the country is still one of the poorest agrarian countries to date in the world. This is simply because the country has failed to transform the smallholder subsistence agriculture. This comprehensive literature review synthesis why the subsistence smallholder agriculture persists in the country. The paper focuses on agricultural development policy issues and practices.
\end{abstract}

Key words: modernization theory, subsistence smallholder agriculture, agricultural development strategy, agricultural extension, technological innovation, national competitiveness

\section{INTRODUCTION}

Ethiopia is an ancient country with unparalleled history; perhaps the country was one of the five world super power wealthiest countries. It has introduced and practiced agriculture no later than the first. However, Ethiopia had slowly impoverished and became the best example of destitute and misery to the extent of Oxford dictionary. This is simply because the country has failed to transform its ancient economic activity that is agriculture. The fact that countries begin economic development only when agriculture provides abundant food for the entire population of a country (Cafiero 2003) justifies you why the country has failed and the necessity of modern agriculture which heavily depends on development and innovation of modern agricultural technologies and practices to transform the entire economy. No country in the world went to the highest economic activity which we all dream for without significantly transformed its agriculture.

Agriculture is an ancient economic base and hence modern development theorists usually label it at the lowest hierarchy of economic activity. The main reason behind the lowest hierarchical position of the sector is primarily due to its (Cafiero, 2003) dependency on the natural environment. Cafiero notes that agricultural production is the result of biological phenomena whose evolution is mainly out of the direct human control. It is sensibly more uncertain than any other sector of the economy. The relative weight of the agricultural sector in the economy varies from country to country. Not to goes back to history, Ethiopian population for instance is a typical example of agrarian society today. Agriculture accounts about 41.6 percent of the GDP, employs about 83 percent of the labor force and contributes around 90 percent of the total export earnings of Ethiopia. The sector is dominated by about 11.7 million smallholders cultivating about 95 percent of the national agricultural production and large farms contributed to only 5 percent of the total production (Demese et al., 2010 and Asfaw, et al., 2011). This shows that the overall economy of the country depends on smallholder subsistence agriculture. Why Ethiopian agriculture has thus not been transformed? Why the sector is still subsistence? These and other related questions have long been dominated the research domain and political economy of the country. I myself have been wondering why my father, a smallholder farmer, has not been producing enough food that can support our family since my childhood. It is not, however, uncommon to read research findings and listen to politicians speaking of biophysical and socio-economic factors; and institutional and agricultural policy issues (see Belay, 2003 and IFPRI, 2010) as the main reasons behind the subsistence agriculture in the country.

An ordinary reader who has inadequate knowledge of the dynamics and strategic interests of the various local and international political and socioeconomic forces could laterally believe that the main reasons behind the persistence of subsistence agriculture in the country cannot be out of and beyond the aforementioned factors. However, there are unexplored factors that contributed to holding the sector back not to transform which need different methodological approach to explore. This does not; however, means the above factors neither have less contribution to the persistence of subsistence agriculture nor there are untouched factors which one can imagine. The underlying factors that hold the subsistence agriculture of the country are very multifaceted and cyclical. This paper therefore intends to outline and synthesis the contributing factors to the persistence of subsistence agriculture. The paper will try particularly to explore the pitfalls of agricultural development policy and practices issues. The paper heavily relies

\footnotetext{
${ }^{1}$ Corresponding Author: ggirmay@gmail.com
} 
on literature review of pertinent published and unpublished source. The author of this paper thus used journal articles, books, policy papers and other relevant documents to construct his argument. The rest of the paper is organized as follows. The second section highlights how the mercenary modernization theory and its policy prescriptions have misled modern agricultural development and practice in the country. The third section is devoted to the contemporary agricultural development policies and practices of the country. The fourth section concludes the paper.

\section{THE MERCENARY MODERNIZATION THEORY}

Theories are hallmarks to development intervention. They determine how states and development practitioners allocate economic resources to development. There are a set of development theories in which states can depend on to formulate national policies and strategies. However, development theories are always value-laden in that theorists and development practitioners have never agreed up on. Whose values and assumptions does each theory constitute is always at the center of the debate. The domination of western values in each development theory and practice with the resultant failure to bring about a significant change in the region supposed to benefit makes evident to the contentious debates and disagreements amongst scholars and development practitioners.

The United States of American President Harry Truman had made a critical speech which vibrated the development discourse in 1949. The President defined Africa, Asia and Latin America as underdeveloped areas which were in need of development (Escobar, 1995). Escobar argues that, on that day, two billion people of the region became underdeveloped and wrapped up into a single homogeneous minority. They were denied being what they were and were transmogrified into an inverted mirror of other's reality. They were relegated into the bottom edge of the global economic system and hence they need development. Harry Truman stated that greater production is the key to prosperity and peace. In his construction of the idea of the third world in need of reformation, Escobar argued that development proceeded by creating abnormalities such as the illiterate, the underdeveloped, the malnourished, small farmers, or landless peasants. The Third World is represented as a child in need of adult guidance (Escobar, 1995). Even if Ethiopia had never been under the colony of any western country, it did not escape from the third world countries category which need.

Immediate after the speech of the president, development theorists introduced new theories and redefined and reshaped the existing theories supposed to lift the poor from poverty trap. Since then on, as Escobar puts it, development has become a top-down, ethnocentric, and technocratic approach, which treated people and cultures as abstract concepts, statistical figures to be moved up and down in the charts of progress (Escobar, 1995). This means development was meant modernization and adoption of western capital, technology, education, policy and planning mechanisms under the Post World War II (PWWII) development project heading. The history of development hence goes back only to the PWWII era, when the apparatuses of knowledge production and intervention were established and when a whole new political economy of truth different from that of the colonial or prewar period was set into place (Escobar, 1992). Let us now highlight modernization theory which had influenced and continue to influence the agricultural development policies and strategies of Ethiopia negatively and failed to bring the desired cake to the country.

Development policies and strategies have long been rooted in the modernization paradigm which assumes the existence of a linear development path and promotes the top-down approaches. The theory held that growth and capitalist led development was the solution to poverty. This development was premised on western investment and underpinned by the transfer of technology. It envisaged an evolutionary development process for countries in the South which would mimic the economic growth path taken by the capitalist North. Early economic development theory equated development with growth and industrialization. As a result, Latin American, Asian and African countries were seen mostly as underdeveloped countries that primitive versions of European nations that could, with time develop the institutions and standards of living of Europe and North America (The New School, 1998 cited in Phuhlisani Solutions, 2009).

W.W. Rostow (1960) has structured modernization theory in his well-known book entitled "The Stages of Economic Growth". Rostow postulated five successive economic growth stages in which societies should undergo in order to modernize and achieve economic development. In the Traditional Society ( $1^{\text {st }}$ stage), economic system is stationary and dominated by agriculture with traditional cultivating forms. Productivity per man-hour is low compared to the next growth stages. Production is labor-intensive using only limited quantities of capital. Technology is limited, and resource allocation is determined very much by traditional methods of production. The Preconditions for Take-off constitutes agricultural transformation and industrial revolution through adoption of modern technologies. Infrastructure development, emergence of entrepreneurship, savings and investment and primary products export are 
the main features of this economic growth stage. A strong central government encourages private enterprise. The Take-off Stage is characterized by dynamic and self-sustained economic growth which requires no exogenous inputs. It involves rapid capital accumulation and early industrialization. Labor and capital shift from agriculture to non-agriculture sector to foster and realize the high industrialization of the Drive to Maturity economic growth stage of Rostow. The economy is diversifying into new areas. Technological innovation provides diverse range of investment opportunities. The economy is producing a wide range of goods and services and there is less reliance on imports. The highest economic growth stage is the Age of High Mass Consumption where the economy gears towards mass consumption, and the level of economic activity is very high. Technology is extensively used but its expansion slows down. The service sector becomes increasingly dominant (Rostow, 1960). Early modernization theorists focused almost entirely on economic growth and capital accumulation models and were largely dismissive of the socio-cultural values of societies in the South, characterizing these as obstacles to development. Unsurprisingly the prescriptions of modernization theory and its neoliberal successors have remained highly contested in the South. However, economic growth remained the founding assumption, although the focus shifted to how to better redistribute economic benefits.

In practice growth-led agricultural and industrial development, irrespective of its ideological packaging or historical era, has had significant social, economic and environmental costs when seen through a global lens. The promised trickledown effect which was premised on economic and social benefits percolating down to the poor largely failed to materialize (Weisbrot etal, 2001). The economic development strategy of the country had been designed to transfer technologies and promote large-scale agriculture since the 1950s and 1960s until the current regime seize power in 1991 and then after proclaim Agricultural Development Led Industrialization strategy which promotes transformation of the smallholder agriculture through diffusion and adaptation of agro-ecology sensitive and laborintensive agricultural technologies and practices. Yet, as we will see below, the contemporary agricultural development strategy of the country has not escaped from the flawed policy prescription of modernization theory. Even if the strategy seems in favor of smallholder farmers laterally, it intrinsically favors the scanty large-holder farmers and foreign investors.

\section{Agricultural Development Strategy and Practices in Ethiopia}

\subsection{Agricultural Development Led Industrialization Strategy}

Poverty has long predominantly been a rural culture. This has always been accorded to wrong development strategies and policies. The persistent poverty and underdevelopment in Ethiopia for example had been ascribed to the absence of appropriate strategies and policies. This was evident during the past two subsequent regimes where the development strategy of the country was urban biased Import Substitution Industrialization (ISI) that accords primacy to industry neglecting peasant agriculture (Getnet and Malek, 2010, Dorosh et al., 2011) which matters the very existence of the majority. Primacy was given to industry in a context where the economy depended on agriculture for its capital accumulation, food supply, raw material, foreign exchange generation, and market. The ISI strategy led to agrarian failure to supply industrial crops, wage goods, foreign exchange, and savings. The growth process of the economy was thus constrained by the limited attention given to agriculture which has resulted on persistent rural poverty and underdevelopment (ibid). The current regime has made a reversal shift from industry first to agriculture first with a particular focus on peasant agriculture known as Agricultural Development Led Industrialization (ADLI) in 1990s. Getnet and Malek (2010) argue that supporters of ADLI believe the agricultural sector to be the leading economic sector and believe that the development of the other economic sectors hinges upon achievements in the agricultural sector.

The ADLI strategy of the country stipulates that the smallholder agriculture is the primary stimulus to generate employment and income, reduce poverty, promote industrialization and ensure a dynamic and self-sustaining growth through the use of modern agricultural inputs (MOFED, 2010). The strategy promotes transformation of the smallholder agriculture through diffusion and adaptation of agro-ecology sensitive and labor-intensive agricultural technologies and practices. It also favors the introduction and application of labor-intensive agricultural technologies over capital-intensive technologies (ibid). This strategy matches with the historical pathway of structural economic transformation that promotes the progressive shift from agriculture to industry and then to services. Losch et a.l (2012) underlined that the underlying dynamic of this structural economic transformation is increased productivity in agriculture which fosters technical change and allows labor and capital to flow to non-agriculture economic activities. It has now been a quarter of a century since the government indorsed and implemented the smallholder agriculture oriented strategy. It is thus important to evaluate to what extent the ADLI strategic environment has been 
reinforced the structural transformation and trigger the shift of labor and capital from rural-based economy usually agriculture to urban center.

Ethiopia has been recording a double digit growth in the last decade. The country has one of the fastest growing economies in the world. The government of Ethiopia is also proclaiming that it has secured food at national level. The future economic growth projection is also very positive to Ethiopia. Many international organizations including World Bank and the International Monetary Fund place the country in the first row list of the fastest economies at least in the near future. According to the recent Business Insider economic growth projection list, for example, Ethiopia will have the fastest growing economy on Earth in the projected years of 2014 and 1017. This is something miracle particularly for Ethiopia which was a model of poverty and misery in the nearest past. However, the recent growth and development record of the country has been resulted in and accompanied by increased poverty, rampant corruption and high inequality. The benefits and beneficiaries of development efforts have largely been the state and its allies. The UNDP (2015) report shows that despite the slight decline over the past decade mostly due to the impressive gains in China; poverty rates remain stubbornly high in South Asia and Sub-Saharan Africa. The report for example discloses that about a quarter of the population in Ethiopia lives under poverty line (UNDP, 2015). Yet, this percentile expression is misleading for those who have little knowledge about Ethiopia. In absolute poverty measures, the country has been experiencing the largest number of poor people on its entire history. The expression a 'quarter' refers to about 25 million people who live under abject poverty in which the country had never been experienced. Similarly, Dercon et al., (2011) argue that the economy of the country has been significantly reformed in the aftermath of the fall of the Marxist-inspired military government Dergue. They found that Ethiopia experienced considerable growth between 1994 and 2009 which has also reflected in growth in assets, education, access to services and roads, and perceived growth in welfare. But the authors reserve that poverty had not been declined between 2004 and 2009.

The structural economic transformation pace of the country has also been very disappointing. The country is home to the largest agrarian society in the planet Earth. According to World Bank (2007) cited in Dorosh et al (2011), the share of agriculture in the national GDP in 2008 (44 percent) was one of the highest in the world and much larger than the average for low income countries (26 percent). The agricultural sector accounted for 56.5 and 58.4 percent of GDP in Ethiopia in the 1980s and 1990s, respectively, before declining to 45.6 percent in the 2000s. This is comparably low even in East African standards. Uganda, one of the fast-growing countries, for example, reduced the share of agriculture to its GDP from 57.6 percent in the 1980s to only 26.2 percent in the 2000s (Dorosh et al., 2011). Currently, agriculture accounts about 41.6 percent of the GDP, employs about 83 percent of the labor force and contributes around 90 percent of the total export earnings of the country. Worst of all, the sector is dominated by about 11.7 million smallholders cultivating about 95 percent of the national agricultural production (MOA, 2010 and Asfaw, et al., 2011). The rural population of the country had also only declined from 95.4 percent in 1950 to 83.9 in 2005 (Dorosh et al., 2011). Dorosh and his colleagues show that the share of agriculture in Ethiopia's GDP declined by $5 \%$ in the last decade while real agricultural GDP growth averaged 6.2 percent over this period, real GDP growth was even higher, at 7.7 percent per year. The authors showed that the structural economic transformation of the country has begun but, they remind, there remains a striking difference between overwhelmingly agriculture dominated economy of the country and the economies of most other developing countries. We can therefore conclude that the ADLI strategy of the country has not been designed to foster rural-urban labor and capital mobility and reinforce structural economic transformation and hence needs a critical revision; otherwise; the country will remain the center of rural poor.

We should also note that the structural transformation requires high agricultural production and productivity that in turn require dynamic land policy and high tech off modern agricultural technologies and practices (see below). However, the story of land policy and development and application of modern agricultural technologies in the country is discouraging. The land policy debate has usually been either in favor of or against to the most popular (state and private) land tenure systems. The author of this paper do not want to talk of in favor of or against to either of them. He rather probes whether the existing tenure system fosters the structural transformation and improves smallholder agriculture productivity or not. The federal government constitution article 40 (3) expatriated the ownership of rural and urban land to the state and the people of Ethiopia once and forever. The constitution further affirms that land is a common property of the people of Ethiopia and shall not be subject to sale and other means of exchange. The constitution and the Rural Land Administration and Use Proclamation No.456/2005 also stipulates that peasant farmers, pastoralists and semi-pastoralists who are or who wish to be engaged in agriculture have only usufruct rights and cannot sell, exchange or mortgage the land. This constitutional provision and legal framework 
not only protects land selling, exchange or mortgage that discourages labor and capital movement from rural areas to urban centers but also it is stationary that cannot change when necessity arises.

Constitutional amendment is not an easy business that the house of peoples representatives of the country can indorse it like other usual proclamation amendments. As clearly stipulated in the federal constitution (article 104), constitutional amendments require the support by a two-thirds majority vote in the house of peoples` representatives, or by a two-thirds majority vote in the house of federation or when one-third of the state councils of the members states of the federation, by a majority vote in each council have supported it, which finally needs the general public consensus. This will rarely possible at least in the near future. I thus argue that the land policy of the country has been designed to detain the rural youth in the rural areas and it hampers structural economic transformation in the country. Dorosh and his colleagues (2011) also assert that the land policy of the country has been designed to slow rural-urban migration through regulatory measures prohibiting sale of land, loss of land rights for those who leave rural areas, and registration requirements for new migrants (see Getnet and Malek, 2010 and Dorosh et al., 2011). The basic reasons of the government to design such a stationery land policy include the fear of mass smallholder displacement, inflation and monetary transfer without value addition and lack of capital. This is however not logically convincing given the mass displacement of smallholder farmers in the name of large scale investment. Smallholder farmers would rather have made a significant change if they were allowed to sell their lands.

On the other hand, the land policy of Ethiopia is propagating smallholder farmers at alarming rate. Agricultural production of the country is characterized by fragmented and dispersed land holdings. The national average farm size is 0.81 hectares with limited irrigation potential (IFPRI and CSA 2006 cited in Dorosh et al., 2011). About 55.7 percent of the farming households in the country cultivate less than 0.5 hectares and about 80 percent of the farmers cultivate less than 1 hectare. Only 4.1 percent of the farmers own more than 2 hectares of land. In addition, the sector is characterized by fragmented farm plots. Plots are at some distance from one another with others' holdings in between. The average number of parcels of land per holder of the 0.81 hectare average holding is 3.3 plots (CSA, 2003 cited in Getnet and Malek (2010). The sector is also dominated by about 11.7 million smallholders cultivating about 95 percent of the national agricultural production (MOA, 2010 and Asfaw, et al., 2011). We must also note that the land policy of the country does not encourage rural-urban labor mobility nor the industry of the country absorbs the labor force from the smallholder farmers. It is now customary to raise one important policy question. Where can the destination of the children of the smallholder farmers be? Where can they make a living? The children of the Ethiopian smallholder farmers have long been left with no options to make a living except expropriating the small parcels of land of their fathers (see Getnet and Malek, 2010 and Dorosh et al., 2011 how rural land transfer and inheritance takes place in Ethiopia).

\subsection{Agricultural Extension Approaches and Practices}

The formal agricultural extension system of the country began in 1950s and 1960s. Agricultural Extension which originally meant enlightenment of local people to promote local innovations is very important in order to unleash the power of scientific knowledge and suit it with the indigenous knowledge. Indeed, the Ministry of agriculture has implemented different extension approaches, such as the Comprehensive Package Program, the Minimum Package Program, the Peasant Agriculture Development Extension Program, the Training and Visit Extension Approach and since 1995, the Participatory Demonstration and Training Extension System (Belay, 2003) over the years. However, these subsequent Agricultural Extension Approaches and Strategies implemented over the last half a century have not brought about a significant change in the smallholder agriculture of the country. Nor these different agricultural approaches have enabled agricultural experts produce relevant agricultural technologies and practices in order to farmers make use of them. The 'western-born agricultural innovations' have been designed on the national research centers and trickled-down to the smallholders. In other words, the contemporary state-run agricultural extension systems and strategies have been geared towards resourceful farmers and have left the resource-poor smallholder farmers under poverty trap; principally because the subsequent extension approaches and strategies pursued have been stemmed from the top-down supply driven development approach which labels farmers as the 'passive recipients' of agricultural technologies; be it relevant or irrelevant to their farming conditions; from the center; usually the 'scientists'. The contemporary Participatory Demonstration and Extension Training System diffuses agricultural technologies to model farmers and then slowly to progressive farmers to outreach the whole community has not benefited the massive smallholders.

As mentioned in the preceding pages, the recent promising national economic growth of the country predominantly comes from favorable weather conditions and resourceful model farmers and other sectors leaving the mass smallholder farmers with farm as usual. There has been little deviation between the agricultural production system of the 
smallholders and their ancestors. The smallholders are still tilling their starved plot of lands either through hoe or oxen. This clear evidence of sluggish change in small-scale agriculture coupled with persistent rural underdevelopment has recently pushed the government to shift from 'diffusion of agricultural innovations' to 'scaling up of innovations and best practices'. This paper thus questions the shift and stance of the government on the agricultural system. The former strategy which has been pursued almost for two decades had been designed to outreach the mass smallholders through model-progressive farmers orientation while the later premises to replicate agricultural technologies and best practices over short period of time to outreach the rural poor. To put it differently, scaling up of modern agricultural technologies by in large requires more resources, agro-ecology sensitive varieties and strong policy and institutional support than the diffusion research. The frontier question now is why has the government changed its agricultural strategy unless otherwise the system has changed?

Scaling up; the current agricultural strategy of Ethiopia; refers to expanding, replicating, adapting and sustaining successful policies, programs or projects in geographic space and over short period of time to reach a greater number of rural poor. It leads to more quality benefits to more people over a wider geographic area more quickly, more equitably, and more lastingly. In Ethiopian diversified environmental and cultural context, however, the scaling up strategy suffers from ecological and composition fallacies. The very essence of the strategy which promotes one technological package to all farming system contradicts with the demand for agro-ecology specific technological solutions policy of the government. Empirically, S. Dercon and D. Gollin (2014) in their African Agriculture Development review of Theories and Strategies have confirmed the absence of single agriculture in Africa and heterogeneity of the sector not only in agro-ecology, but also in socio-economic, institutional and political settings. This is a typical characteristic of Ethiopian agriculture where the farming system and farmers condition are heterogeneous all over the country. Unlike this, the same agricultural inputs have long been disseminated to all farming conditions in the country and hence subsequently failed to transform the smallholder agriculture. This is evident in the application of artificial fertilizer. The same fertilizer (DAP and Urea) has been supplied in the country since the introduction of the technology in 1960s. This application of the same technology across the country has brought little change in the productivity of the sector. The provision of DAP and Urea across the country has sometimes been the same as provision of soil nutrients which are already adequate in the soil.

\subsection{Agricultural Research and Technological Innovation}

This section presents agricultural research and technological innovations in Ethiopia but it first highlights the concept of technology and innovation. Technology development refers to verification, generation, and improvement of technology. Technology can be equipment, tool, machine, variety, management practice, information, organization or a combination of either of these which brings about improvement in production, productivity, profitability, quality and reduce risk (Bedru etal, 2009). The technology needs to be appropriate, which is compatible with resources, such as labor, skills, materials and capital, available to target farmers and products that are suited to targeted community as well as the market (ibid). On the other hand, innovation can be described as the means by which individuals and groups apply their creative, adaptive capacities and their social, organizational, and institutional knowledge for the generation and application of new scientific and technical knowledge. It the application of technological, institutional and human resources and discoveries to productive processes, resulting in new practices, products, markets, institutions and organizations that are improved and efficiency-enhancing (Poole and Buckley, 2006). Innovation encompasses the work of both formal Science and Technology enterprises, and the informal, grassroots ideas and inventions of people not associated with official institutions (ICSU, 2005). Since most of the innovations are technological inventions, we use the phrase "Technological Innovation" to refer to the generation and application of a technology in order to improve the productivity of agriculture (Diaconu, 2011).

Innovation involves putting ideas, knowledge and technology to work in a manner that brings about a significant improvement in performance. Innovation is thus the commercialization and actual use of the invention itself (IFAD, 2013). This implies that unless embedded with existing knowledge, political, socio-economic, organizational setting and cultural context, a new technology fixation or model provision does not lead to innovative agricultural practice and transformation which has been lacking in Ethiopia. The recent Business Process Reengineering (BPR), Business Scorecard (BSC) and Kaizen innovative development models that aim at improving the overall performance of institutions are typical examples of innovations. However, the BPR and BSC innovative development models either have failed or not yet brought significant changes in many of the public institutions in the country. In agriculture, innovation involves innovating or demonstrating new programmatic agricultural technologies and innovations like introduction to and application of improved varieties, methods and adaptable practices. They include new crop varieties and hybrids, the green house technology, genetically modified food, chemical fertilizers, insecticides, 
tractors and the application of other scientific knowledge and production methods; and new marketing skills (Matunhu, 2011).

The formal Agricultural Research works in Ethiopia began in 1950s and 1960s. Since the establishment of the Agricultural Research Institute in 1966, Ethiopia has a national agricultural research system with an autonomous management and with major and minor stations covering the major ecological zones, and the major commodity and discipline groups (Belay, 2003). Agricultural technologies are key factors to increase agricultural production and stimulate the national economy. Indeed, the government of Ethiopia has restructured the national research system by establishing the Ethiopian Agricultural Research Organization in 1997 (Proclamation No. 79/1997). This proclamation was prepared with the presumption that new technologies will be generated, indigenous knowledge will be improved, exotic technologies will be adapted and new scientific knowledge and information will be developed in line with the country's ADLI Strategy.

The Ethiopian Agricultural Research organization has restructured in six wings in order to achieve its strategic goal. These are Crop Research Strategy, Livestock Research Strategy, Dry Land Research Strategy, Soil and Water Research Strategy, Forestry Research Strategy, Socio-economic Research Strategy, and Research Extension Research Strategy. Research centers have also been separated from and added to the institute over the years; some sub-centers were upgraded to create new centers, and others were merged. The Regional Agricultural Research Institutes which have expanded significantly over time are managed by regional state governments. The Ministry of Science and Technology has virtually no connection with Ethiopian Institute of Agricultural Research (Flaherty et al, 2010). The authors note that the total public expenditure on agricultural Research and Development increased from the 1990s onward at a relatively steady rate. The total expenditure increased significantly after 2000, peaking in 2001-02 as a combined result of government and donor support resulting in a total capacity of 1,318 full-time equivalent research staff in 2008. This expenditure growth was primarily driven by greater government and donor funding to Ethiopia's main agricultural research agency, the Ethiopian Institute of Agricultural Research (EIAR). Ethiopia's agricultural research staffing is among the least qualified in Africa in terms of postgraduate degrees, and female participation is also comparatively low (ibid).

Fig1 (a). Agricultural Research and Development Fig1 (b). Agriculture Research Staff in Full Time Expenditure Adjusted for Inflation, 1993-2008 Equivalents; 1993-2008

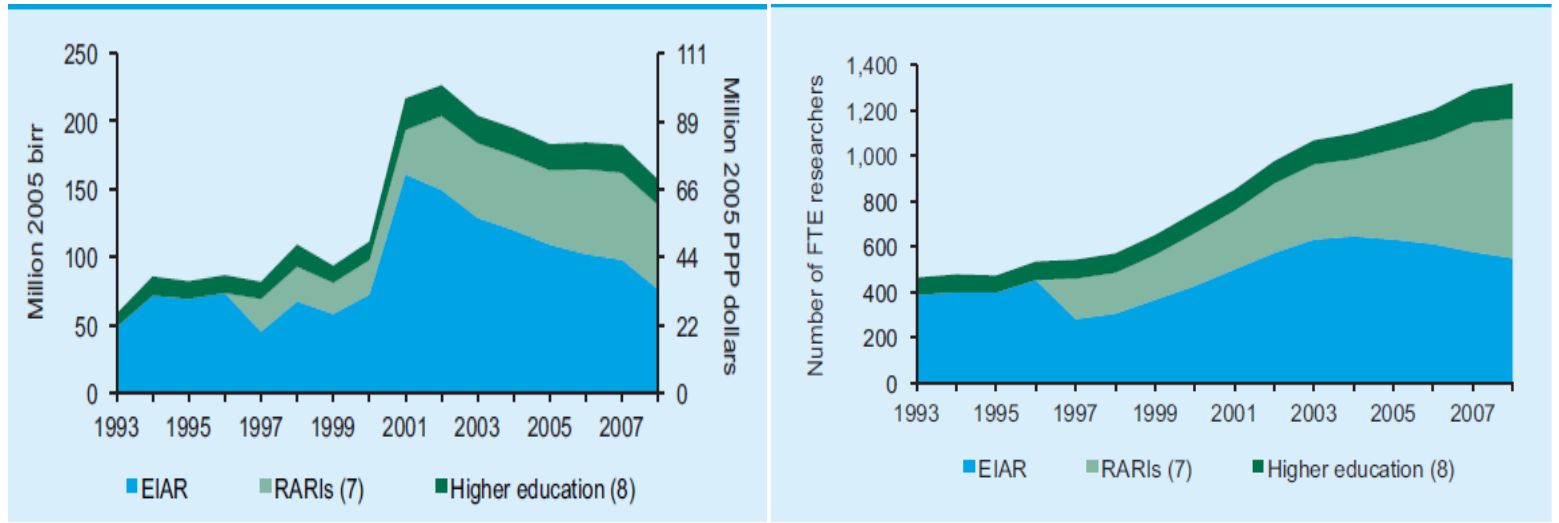

Source: Flaherty et al (2010)

The agricultural research intensity ratio, or total public spending on agricultural Research and Development as a percentage of agricultural GDP, is a common indicator of comparative agricultural Research and Development spending across countries. Ethiopia's ratio rose sharply after 2000, reaching $\$ 0.65$ in 2002. While this level is still comparatively low, it reflects the country's increased spending on agricultural Research and Development at that time. By 2008, however, the ratio had returned to 2000 levels. That year, for every 100 USD of agricultural output, 0.27 USD was invested in agricultural Research and Development which is very low compared with other countries, such as Kenya and Tanzania whose ratios in that year were 1.43 USD and 0.50 USD respectively (Flaherty et al, 2010). The number of agricultural researchers per million farmers is also another indicator of public spending on research and Development. The number of agricultural researchers per million farmers rose more steadily in Ethiopia after the 1990s, reaching 43 FTEs in 2008. However, the 2008 agricultural intensity ratio of 0.27 USD is one of the lowest ratios in the region, and funding remains highly dependent on donors and development bank loans. 
Delays in the disbursement of funds also present a significant challenge to the effective management of research expenditures in the country (ibid).

Fig2. Intensity of Agricultural Research Spending and Capacity, 1993-2008

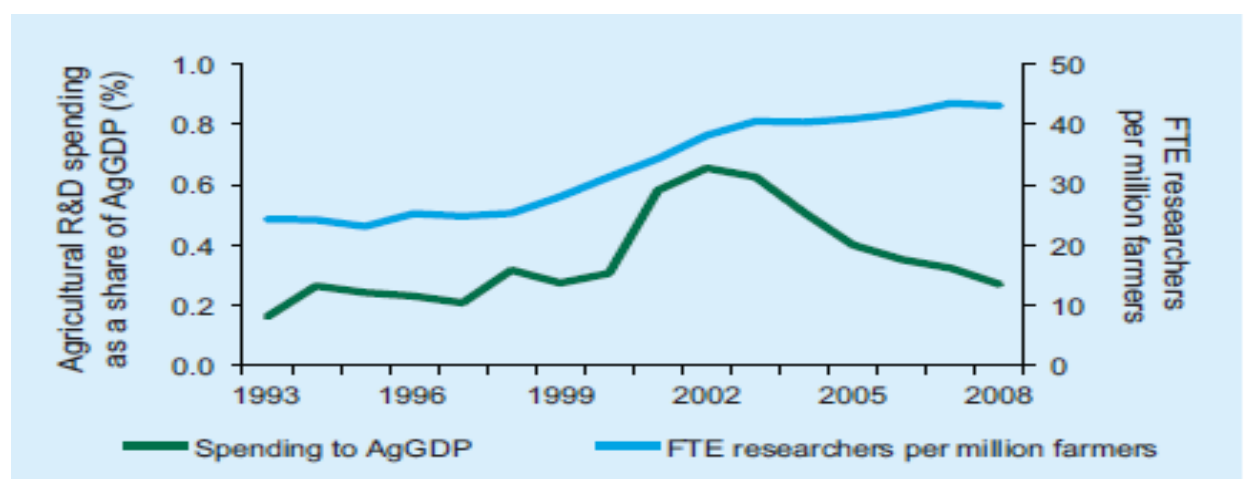

Source: Flaherty et al (2010)

The aforementioned subsequent institutional reforms and public expenditures, however, have neither promoted local innovations nor technological adaptations that have the potential to bring the necessary agricultural transformation in the country. Tesfaye (2003) underscored that Agriculture and rural development in Ethiopia remains delivery oriented in terms of its extension services rather than encouraging farmers' innovations. For Tesfaye, the preconceived government and non-governmental organizations interventions ignore the potentials of the local resources, local innovations and needs.

Therefore, (Workneh, 2013) the external supports have, in many cases failed, to ensure sustainable development. The technological inputs that have been identified and packaged by outsiders, with very little or no consultation of the smallholder farmers, were not able to respond adequately to local realities. Although there are some professionals who begun to appreciate the participation of farmers in technology development, many are still trapped in what is known as top down, center-outwards institution, agricultural technology generation and transfer thinking and action, where researchers determine priorities, generate technologies and transfer them to farmers via extension (ibid). Friis-Hansen and Egelyng (2007) in the same source also indicated that scientific research results produced by on-station research do not always meet small-scale farmers' requirements for the complex environments in which they live and produce.

Amanuel Assefa (2005) also reaffirms that the government and aid agencies in the country are always trying to provide supports to farmers. For Amanuel, the philosophy of their supports reflects paternalistic view. These agencies feel responsible to take care of the farmers and the only thing farmers are expected to do is receive and use the supports; in accordance to the instructions and guidance they are given by those agencies. This tradition has therefore continued to create dependency on external supports, demanding for more every time and yet without showing adequately sustaining changes. On the other hand, Amanuel argues, despite the immense potentials we have in the country, the local innovations and other resources remain untapped. In the formal research system, there is lots of progress in adopting participatory approaches for research but there is no conscious and systematic linkage between the agricultural scientists and farmer innovators (ibid).

\subsection{Agricultural Science and Technology Application}

This section highlights the significance of science and scientific knowledge to agricultural development. The ability of a country to sustain rapid economic growth in the long run is highly dependent on the effectiveness with which its institutions and policies support the knowledge generation, technological transformation and innovativeness of its enterprises. Science, technology and innovation are the cornerstones of progress upon which a nation depends to attain economic growth and vibrant integrated self-sustaining economy. The imperativeness of science and technology to [agricultural] development has also long been recognized. Schultz (1964) for example has noted that the man who farms as his forefathers did, cannot produce much food, no matter how rich the land or how hard he works. In contrast, Schultz argues that the farmer who has access to and knows how to use what science knows about soils, plants, animals and machines can produce an abundance of food though the land could be poor nor need he works nearly so hard and long (ibid). 
The idea of Schultz tells us that unless farmers use what modern science dictates about agriculture and application of modern agricultural technologies and inputs, they could not improve their farm productivity. Unfortunately, Schultz`s scientific agricultural doctrine has not yet prevailed on majority of smallholder farmers in the country today whose average grain yield per hectare remains stagnant. The sector is characterized by traditional farming where land, traditional tools, draft animals and family labor are still the most important factors of production in the country. I have lively witnessed that this traditional farming in all my professional walks in the rural areas of the country. I have observed little deviation between the agricultural production system of the smallholders and their ancestors. In other words, the smallholders are still tilling their starved plot of lands either through hoe or oxen.

In contrast to this, Science and technology has generated new knowledge and skill, and has dramatically contributed to the development and progress of people's lives, the economy, and the society around the world. The rapid advances in sciences for example had contributed to the Green Revolution which has largely transformed the global agriculture during the 20th century (Hagell, 2009). The story of English wheat is typical. It took nearly 1000 years for wheat yields to increase from 0.5 to 2 tons per hectare, but then wheat yields climbed to over 7 tons per hectare during the 20th century. These advances were fueled by modern plant breeding, improved agronomy, and the development of inorganic fertilizers and modern pesticides. Most industrial countries had achieved sustained food surpluses by the second half of the 20th century and abolished the threat of food shortages. This $20^{\text {th }}$ century scientific revolution had created a regional disparity and led to the widespread hunger and malnutrition by the 1960s, especially in developing Asia (ibid). This widespread poverty and hunger called for further scientific advancement and technological solution of the Asian Green Revolution of the 1965-1990 (CGIAR Science Council, 2005).

There is also strong evidence that affirm scientific knowledge and technological innovations increase the productivity and production of agriculture. The 20th century scientific revolution in agriculture for instance had abolished the chronic famine and hunger in Asia and the resultant increases in food production pulled the region back from the edge of an abyss of famine and led to regional food surpluses within 25 years (Hagell, 2009). The Green Revolution in Asia was attributed to the development and adoption of fertilizer-responsive, high-yielding modern rice and wheat varieties, irrigation, and pesticides,-that together dramatically increased crop production and a supporting economic and policy environment. The revolution was also a socio-economic and political construct. The author underlined that agricultural input subsidies, access to credit and markets, irrigation systems, government price support and infrastructure improvement were important factors of the revolution. The revolution improved the grain production in tropical Asia more than doubled and the per capita food production significantly increased over the last few decades. The relative absence of these modern agricultural inputs have been one of the [most] important factors holding back agricultural development in Africa compared to other developing regions (ibid).

The absence and low development, adoption and application of modern agricultural inputs (chemical fertilizer, improved seeds, pesticides and irrigation) are evident in Ethiopia. The smallholder agriculture of the country is characterized by low input-output rain-fed smallholder farmers. Chemical fertilizer use for example is low. Only 30 40 percent of Ethiopian smallholders use fertilizer (Spielman etal, 2013). The physical application rate of fertilizer is also well-below those recommended by the extension programs; on average only 37-40 kilogram per hectare (in 2013) compared with an average of $102.0 \mathrm{~kg}$ fertilizer use per hectare across Asia in 1995 (Hazell, 2009). The adoption of fertilizer responsive improved seed has also been very slow in the country. Farmers used improved seed covered an average of only 4.7 percent of cropped area in 2007/08 cropping year (Spielman etal, 2011). This absence and low development and application of agricultural technologies, among others, can be due to the failure to (CGIAR Science Council, 2005) unleash the power of science. The council underscored that science and scientific knowledge have the power to create wealth and reduce poverty. The smallholder farmers cannot buy the high tech off western modern agricultural technologies nor generate them locally. The smallholder subsistence agriculture thus still persists because the country fails to unleash the power of agricultural science and technological innovations to transform the sector. In addition, (Norton et al, 2010) transfer of modern agricultural technologies from the west has long been proved to be failed.

\section{NATIONAL INNOVATION COMPETITIVENESS}

Ethiopia has abundant lobar force and land but it lacks two of the most important factors of production that is capital and innovation. As stated in the preceding pages, scientific knowledge and technological innovations have the power to create wealth and reduce poverty. I do believe, however, that agriculture is still subsistence because the country fails to unleash the power of agricultural science and technological innovations to transform the smallholder agriculture. This section thus discusses the national innovation competitiveness of Ethiopia in the international 
forum. We should not also forget that the economy of the country is made up smallholder agriculture and hence the national innovation competitiveness of Ethiopia in the international forum largely reflects the status of agriculture.

The country has not yet undergone scientific and technological revolution. This failure to revolt in science and technology could be attributed to multidimensional factors that have long been lacking in the country. Innovation is the function of highly skilled workforce who have significant research and development intensity and close linkages to the centers of excellence in the scientific world; financial resources allocation to research and development activities; physical infrastructures which serve as a basis for entrepreneurial activity, property right protection; and governance (IKED, 2006 and Diaconu, 2011) which all have long been lacking in Ethiopia. The most common measures of national innovation competitiveness include (i) the share of high-technology products in exports, as a measure of the ability to compete internationally in technology; (ii) registered patents, as a measure of the output of possible marketable new innovations; (iii) scientific publications, as a measure of how competitive the academic community is; and the number of Nobel Prize winners (ibid).

Ethiopia has a poor performance record in all of the aforementioned national innovation competitiveness in the international arena. The World Economic Forum's (2004) African Competitiveness Report for example ranks Ethiopia number 19 out of 25 sub-Saharan economies and the twelfth least competitive country in the world. The growth competitiveness index is composed of three sub-indices related to the quality of public institutions, the macroeconomic environment, and the capacity to produce and adapt technology. According to the report, it is in the area of technology production and adaptation that Ethiopia performs worst. Ethiopia's exports have no hightechnology content. In terms of patents and scientific articles indicators, the country had little record of innovation system. Resident and non-resident applications to the national patent office are scarce, and in the prior 10 years of the World Economic Forum`s (2004) African competitiveness report, there have been no applications from Ethiopian nationals to the United States patent office, compared to almost 200 from Kenya and nearly 1300 from India.

As mentioned in the preceding pages, innovation requires highly skilled workforce who have significant research and development intensity and close linkages to the centers of excellence in the scientific world. However, modern education which was introduced to Ethiopia nearly a century ago has little contribution to local innovation. The Ministry of Education (2002) proves that the education system of the country had limited positive impact on the lives of the people and national development. The education offered has not enabled to solve the problems of farmers, pastoralist, and change the lives of the over whelming majority of the people. Without capable people who are able to invent technologies or adapt it, innovation cannot happen. The innate ability to innovate is usually reinforced by literacy, education, and exposure to new ideas backed up by good health and well-being. However, only less than half of the adult population is literate in the country. Even the innovation ability of the elite group is affected by institutional bottlenecks and resource constraints. The central question every of us can ask, however, should be why Ethiopia which has introduced modern education system a century ago have poor innovation competitiveness requires further enquiry.

Table1. Ethiopian innovation competitiveness

\begin{tabular}{lcccc}
\hline & $\begin{array}{c}\text { Patent applications, per million } \\
\text { people, 1999 }\end{array}$ & $\begin{array}{c}\text { Patent applications } \\
\text { to the US PTO } \\
\text { Non-residents }\end{array}$ & $\begin{array}{c}\text { Scientific and technical journal } \\
\text { articles, per million people, 1999 }\end{array}$ \\
\cline { 2 - 5 } Ethiopia & 0.05 & 0.10 & 0 & $1 /$ \\
\hline Kenya & 0.07 & 4895 & 192 & 1.5 \\
Tanzania & 0.06 & 4318 & 2 & 8.4 \\
\hline Uganda & 0.08 & 6287 & 5 & 2.7 \\
Indonesia & 0.0 & 370 & 57 & 2.5 \\
\hline India & 0.23 & 76 & 1271 & 0.7 \\
OECD & 586 & 47396 & -- & 9.1 \\
\hline
\end{tabular}

Source: WDI (2004) and USPTO (2004)

\section{CONCLUSION}

Ethiopia is an ancient country with unparalleled history. It has introduced and practiced agriculture no later than the first. However, the country is still one of the poorest agrarian countries to date in the world. This is simply because 
the country has failed to transform the smallholder subsistence agriculture. This comprehensive literature review synthesis why the subsistence smallholder agriculture persists in the country. The paper tries to syntheses the pitfalls of agricultural development policies and practices issues.

The paper concludes that the western-born top-down development theories and policy prescriptions coupled with wrong subsequent development strategies and practices slow-down the structural economic transformation of the country and detain the rural youth in the rural areas and hold the smallholder agriculture subsistence. It also draws that the smallholder agriculture persists in the country due to the stationery land policy that detains the rural youth in the rural areas, top-down agricultural extension systems and approaches, the poor agricultural research and technological innovations which do not trigger local innovations; and primarily the failure of the country to unleash the power of agricultural science and technological innovations to transform the smallholder agriculture due to the wrong educational system.

The country has also low national innovation competitiveness in the international arena. This poor national innovation competitiveness is ascribed to the absence of highly skilled workforce; low investment on research and development, unsecure intellectual property right; and bad governance. The Ethiopian agricultural research intensity ratio is low even in African standards. The formal agricultural research system of the country does not encourage local innovation nor generates modern agricultural technologies and inputs compatible with the existing knowledge, political, socio-economic, organizational setting and cultural context of the smallholder farmers. Hence, it is imperative to rethink and reshape the agricultural development strategy, land policy, modern agricultural input supply system; and research and technological innovation system of the country to transform the smallholder agriculture and revolt the overall national economy.

\section{REFERENCES}

[1] Amanuel Assefa (2005). Challenges and prospects of Farmer Innovation in Ethiopia: Presented in the workshop organized by IFAD under the theme "what are the innovation challenges for rural development" on 15-17 Nov 2005, Italy, Rome

[2] Asfaw, etal (2011). Livestock Production and Marketing. ESSP II Working Paper.

[3] Bedru B., etal, (2009). Guideline to Participatory Agricultural Research through Farmer Research Group (FRG) for Agricultural Researchers, Melkassa Agricultural Research Centre and Adami Tulu Agricultural Research Centre in collaboration with EIAR, OARI and JICA.

[4] Belay, Kassa (2003). Agricultural Extension in Ethiopia: the Case of Participatory Demonstration and Training extension System, Journal of Social Development in Africa, Volume 18, Issue No 1, pp. 49-84.

[5] Cafiero (2003).Agricultural Policies in Developing Countries: Training Material, National Agricultural Policy Center, Syrian Ministry of Agriculture and Agrarian Reform

[6] CGIAR Science Council (2005) Science for agricultural development: Changing contexts, new opportunities. Rome, Italy: Science Council Secretariat.

[7] Diaconu M. (2011). Technological Innovation: Concept, Process, Typology and Implications in the Economy, Theoretical and Applied Economics, Volume XVIII, No. 10 (563), pp. 127-144.

[8] Demese et al., (2011). Ethiopia`s Agricultural Sector Policy and Investment Framework (2010- 2020).

[9] Dercon et al., (2011). Growth and chronic poverty: Evidence from rural communities in Ethiopia, CSAE Working Paper [WPS/2011-18]

[10] Dercon S. and Gollin D. (2014). Agriculture in African Development: A Review of Theories and Strategies, CSAE, Working Paper, Oxford University.

[11] Dorosh P. etal (2011). The Rural-Urban Transformation in Ethiopia, the Ethiopian Strategy Support Program II, IFPRI and EDRI.

[12] Escobar, Arturo (1992). Imagining a Post-Development Era? Critical Thought Development and Social Movements, Duke University Press, pp. 20-56.

[13] Escobar, Arturo (1995). Encountering Development: the Making and Unmaking of the Third World. Princeton University Press, Princeton, New Jersey.

[14] Federal Democratic Republic of Ethiopia (2005). Proclamation no. 456/2005, rural land administration and land use proclamation. Addis Ababa: Federal Democratic Republic of Ethiopia.

[15] Getnet and Malek (2010). Implications of Land Policies for Rural-urban Linkages and Rural Transformation in Ethiopia, Ethiopia Strategy Support Program (ESSP) II Working Paper No. 15, IFPRI and EDRI.

[16] Jhamtani (2010). The Green Revolution in Asia: Lessons for Africa, FAO

[17] Hazell, Peter B.R. (2009). The Asian Green Revolution. IFPRI Discussion paper 00911 
American Research Journal of Agriculture, Volume 1, Issue 3, 2015

[18] International Council for Science (2005). Harnessing Science, Technology, and Innovation for Sustainable Development: A report from the ICSU-ISTS-TWAS Consortium ad hoc Advisory Group.

[19] IFPRI/ International food Policy Research Institute (2004). Agriculture, food security, nutrition and the MDGs. Washington, DC.

[20] IFAD/International Fund for Agricultural Development (2013). The importance of scaling up for agricultural and rural development: A success story from Peru, Rome, Italy, IFAD Occasional Paper

[21] IKED/International Organization for Knowledge Economy and Enterprise Development (2006). Ethiopia: Innovation and Growth in international comparison: Prepared for Triple Helix Conference on Transforming University-IndustryGovernment Relations in Ethiopia

[22] Losch et al., (2012). Structural Transformation and Rural Change Revisited: Challenges for Late Developing Countries in a Globalizing World. African Development Forum series. Washington DC: World Bank. DOI: 10.1596/978-0-8213-9512-7. License: Creative Commons Attribution CC BY 3.0

[23] Matunhu, J. (2011). A critique of modernization and dependency theories in Africa: Critical assessment, African Journal of History and Culture, Vol. 3(5), pp. 65-72.

[24] MOFED (2010). Growth and Transformation Plan (GTP) 2010/11-2014/15.

[25] Ministry of Education (2002). The Education and Training Policy and its implementation.

[26] Norton et al, (2010). Economics of Agricultural Development: World Food Systems and Resource Use, Second edition, Routledge Taylor and Francis Group, London and New York.

[27] Phuhlisani Solutions (2009). International and local approaches to rural development Key issues and questions: A review of the literature for the Drakenstein Municipality

[28] Poole and Buckley (2006). Innovation challenges, constraints and opportunities for the rural poor, IFAD

[29] Proclamation No. 79/1997. A Proclamation to Provide for the Establishment of the Ethiopian Agricultural Research Organization. $3^{\text {rd }}$ Year No.42. $5^{\text {th }}$ June 1997. Addis Ababa.

[30] Rostow W.W (1960). The Stages of Economic Growth: A Non-Communist Manifesto, Cambridge.

[31] Schultz T. W. (1964). Transforming Traditional Agriculture, Chicago, University of Chicago Press.

[32] Spielman etal (2011). Seed, Fertilizer, and Agricultural Extension in Ethiopia, Ethiopia Strategy Support Program II (ESSP II) Working Paper 020

[33] Tesfaye Beshah (2003). Understanding Farmers: Explaining Soil and Water conservation in Konso, Wollita and Wollo, Ethiopia

[34] United States Patent and Trademark Office (2004), Patent counts by country, state and year, Washington, D.C.

[35] Weisbrot, M. etal (2001). The Scorecard on Globalization 1980-2000: Twenty Years of Diminished Progress. Washington: Center for Economic and Policy Research.

[36] Workneh et.al (2013). Effectiveness of Local Innovation Practices in Selected Districts of West Shewa Zone, Ethiopia, Wudpecker Journal of Sociology and Anthropology, Vol. 1(4), pp. 041- 046.

[37] World Bank. 2007. World Development Report 2008: Agriculture for Development, Washington, DC. 